\title{
FAKTOR-FAKTOR YANG MEMPENGARUHI PERILAKU MEMILIH PEMULA PADA PEMILIHAN KEPALA DAERAH KABUPATEN NGADA TAHUN 2015
}

\author{
Yohana Apaut, Arry Bainus, Dede Sri Kartini \\ Program Pascasarjana Ilmu Politik FISIP Universitas Padjadjaran \\ Email: yohanaapaut@yahoo.co.id
}

\begin{abstract}
Abstrak
Pemilih pemula dalam pemilihan kepala daerah memberikan sumbangsih suara yang sangat diperhitungkan. Namun disadari perilaku pemilih pemula yang masih labil dan belum mempunyai pengalaman dalam mengikuti pemilihan umum menjadi sasaran dari setiap pasangan calon menjadikan suara pemilih pemula sebagai salah satu lumbung suara dari pasangan calon. Tujuan dari penelitian ini adalah untuk menganalisis seberapa tinggi pengaruh identifikasi partai, orientasi calon orientasi isu dalam mempengaruhi perilaku memilih pemula kabupaten Ngada tahun 2015.Teknik analisis data yang digunakan adalah Structural Equation Modelling (SEM) dengan program LISREL. Hasil penelitian ini menunjukan variabel Identifikasi partai berpengaruh terhadap perilaku memilih pemula sebesar $33,6 \%$ dan variabel orientasi calon berpengaruh terhadap perilaku memilih pemula sebesar $27,7 \%$ dan orientasi isu berpengaruh 18,2\% terhadap variabel perilaku memilih pemula. Dengan t-value standart 1,986 besaran pengaruh ketiga variabel tersebut lebih besar dari t-value $(1,986)$ maka dapat dikatakan variabel identifikasi partai, orientasi calon, orientasi isu berpengaruh signifikan terhadap perilaku memilih pemula kabupaten Ngada pada pelaksanaan pemilihan kepala daerah tahun 2015.
\end{abstract}

Kata kunci: Perilaku Pemilih Pemula, Kabupaten Ngada 


\section{Pendahuluan}

Demokrasi sebagai suatu sistem, kebijakan umum ditentukan atas dasar mayoritas oleh wakil-wakil yang diawasi secara efektif oleh rakyat dalam pemilihan-pemilihan bersekala yang didasarkan atas prinsip kesamaan politik dan diselenggarakan dalam suasana terjaminnya kebebasan politik ${ }^{1}$. sebagai warga negara yang memiliki kedaulatan tertinggi mempunyai hak yang melekat didalam individu masing-masing, yakni hak sebagai warga negara, hak politik dan hak sosial. Hakhak ini bersifat aktif maupun pasif baik secara langsung-maupun tidak yang mendukung kebijakan-kebijakan pemerintah sebagai bentuk peran serta masyarakatnya untuk berpartisipasi dalam kehidupan politik. Negara dikatakan demokratis apabila pemegang kekuasaan tertinggi berada ditangan rakyat, negara yang menjamin kebebasan rakyatnya, kebebasan menggunakan hak politiknya untuk memilih dan dipilih. Secara umum demokrasi diartikan sebagai pemerintahan dari rakyat oleh rakyat dan untuk rakyat. ${ }^{2}$ Rakyat memiliki kebebasan untuk memilih pemimpin negara, parlemen maupun daerahnya sendiri yang dianggap memiliki kompetensi yang baik dan bisa mereka percayai untuk membangun daerah mereka sendiri. Untuk itu negara yang menganut sistem demokrasi perlu adanya Pemilihan umum yang merupakan suatu sarana yang diakui secara hukum dan undang-undang dan dapat dipercayai untuk memilih wakilwakil rakyat yang bisa memimpin negara maupun daerahnya.

Pemilu merupakan mekanisme dalam memilih pemimpinpemipin yang akan menduduki jabatan-jabatan politik pada lembaga-lembaga formal baik lembaga eksekutif maupun lembaga legislatif, ditingkat pusat dan daerah. Pemilu merupakan sarana bagi warga masyarakat untuk memilih

\footnotetext{
${ }^{1}$ Henry B.Mayo, An Introduction to Democractic Theory (New York: Oxford University Press, 1960) hal.70.

${ }^{2}$ Saiful Mujani dan R. Wiliam Liddle dan Kuskridho Ambardi, Kuasa Rakyat Analisis tentang Perilaku Memilih dalam Pemilihan Legislatif dan Presiden Indonesia Pasca-Orde Baru (Jakarta Selatan: Mizan Publika, 1992) hal, 76
} 
pemimpin kepala negara maupun kepala daerah bagi negara yang menganut sistem pemerintahan demokrasi. Masyarakat sebagai pemilih memiliki posisi yang sangat penting dalam pemilihan umum begitupun dalam pemilihan kepala daerah (Pilkada), sukses tidaknya sebuah pemilu ditentukan oleh pemilih. Tanpa adanya pemilih tidak akan terlaksananya pemilihan umum, pemilihlah yang menjadi aktor terpenting dalam pemilihan umum.

Batas usia minimum pemilih untuk menggunakan hak politiknya yakni 17-21 tahun pada saat pelaksanaan pemilu, yang disebut juga sebagai pemilih pemula. Pemilih pemula memiliki perilaku yang masih labil dan belum memiliki pengetahuan yang luas menegenai arti penting dari pemilu, setiajid menjabarkan karakteristik pemilih pemula; pertama, belum pernah memilih atau menentukan suara didalam Tempat Pemungutan Suara (TPS); kedua, belum memiliki pengalaman dalam memilih; ketiga, memiliki sikap ingin tau yang tinggi; keempat, kurang rasional; kelima, pemilih pemula cenderung penuh gejolak dan semangat, apabila tidak di kendalikan akan memberikan dampak pada masalah-masalah sosial didalam pemilu; enam, menjadi sasaran peserta pemilu karena jumlahnya cukup banyak; tujuh, memiliki rasa ingin tahu yang tinggi, mencoba, dan berpartisipasi dalam pemilu walaupun berasal dari berbagai latar belakang yang berbeda. ${ }^{3}$

Selanjutnya, Setiadjid mengungkapkan bahwa pemilih pemula memiliki kedudukan dan makna strategis dalam Pemilu alasannya, pertama, secara ukuran jumlah, pemilih pemula mempunyai jumlah yang cukup banyak didalam masyarakat; kedua, merupakan bagian dari pemilih yang memiliki pola yang rumit untuk diatur dan diprediksi; ketiga, lebih cenderung memilih sikap golput; keempat, masing-masing organisasi sosial politik megklaim sebagai organisasi yang sangat sesuai untuk menyalurkan aspirasi bagi pemilih pemula.

${ }^{3}$ Setiadjid, Orientasi Politik yang Mempengaruhi Pemilih Pemula dalam Menggunakan Hak Pilihnya Pada Pemilihan Walikota Semarang tahun 2010 (Jurnal Politik No 1,2011) hal. 20. 
Namun, disadari pemilih pemula memiliki potensi dan permasalahan yang kompleks, yaitu heterogenitas baik umur, status sosial, maupun permasalahan aspirasi kepentingan dan kartekter pribadi yang khas, yaitu dinamis, labil, sensitif dan berani. Namun perilaku yang labil, sensitif dan mudah untuk dipengaruhi dimanfaatkan oleh partai pendukung kontestan untuk meraih jumlah suara sebanyak-banyaknya dalam pilkada. Pemilih pemula adalah, pemilih yang baru pertama kali atau baru sekali menggunakan menggunakan hak pilihnya, mereka kurang memiliki dasar tentang politik dan belum punya pengalaman dalam menggunakan hak suaranya ${ }^{4}$. Minimnya pengetahuan dan wawasan dalam politik dikarenakan tidak adanya pendidikan politik yang diajarkan baik dilingkungan keluarga, lingkungan sekolah maupun lingkungan sekitar tempat tinggalnya. Sikap acuh terhadap kejadian ataupun fenomena politik yang terjadi merupakan salah satu penyebab pemlih pemula kurang memahami permasalahan politik yang terjadi

Kabupaten Ngada merupakan salah satu kabupaten di Indonesia yang menyelenggarakan pemilihan kepala daerahnya pada tahun 2015. Pilkada kabupaten Ngada diikuti oleh tiga kandidat yakni, pasangan calon Kornelis Soi dan Joseph Bei, Pasangan calon Paulinus No Watu S.Sos dan Bernadus Dhey Ngebu, SP, pasangan calon Marianus Sae S.A. dan Drs. Paulus Soliwoa. Suksesnya pemilihan kepala daerah kabupaten ngada tidak terlepas dari partisipasi pemilih terutama pemilih pemula kabupaten Ngada tahun 2015. Jumlah pemilih pemula 13.104 atau 6\% dari jumlah DPT memiliki potensi yang cukup bagus sebagai lumbung suara para kandidat untuk meraih suara yang banyak dalam pemilihan kepala daerah kabupaten Ngada tahun 2015. Pesebaran jumlah pemilih pemula kabupaten Ngada di 12 wilayah kecamatan kabupaten Ngada dapat dilihat pada tabel dibawah ini.

${ }^{4}$ Rudini, Atas Nama Demokrasi (Jakarta: Bigraf Publising, 1994) hal.109

Jurnal TAPIs Vol. 14 No.02 Juli-Desember 2018 
Yohana Apaut, dkk: FAKTOR-FAKTOR YANG

Tabel 1.

Jumlah Pemilih Pemula Kabupaten Ngada Pada Pilkada Tahun 2015

\begin{tabular}{|c|c|c|c|c|c|c|c|}
\hline \multirow[t]{2}{*}{ NO } & \multirow{2}{*}{$\begin{array}{c}\text { Kecamata } \\
\mathbf{n}\end{array}$} & \multicolumn{2}{|c|}{ Jumlah Pemli } & \multicolumn{4}{|c|}{$\begin{array}{c}\text { Jumlah Pemilih Pemula } \\
\text { (17-21 tahun) }\end{array}$} \\
\hline & & $\mathbf{L}$ & $\mathbf{P}$ & $\mathbf{L}+\mathbf{P}$ & $\mathbf{L}$ & $\mathbf{P}$ & $\mathbf{L}+\mathbf{P}$ \\
\hline 1 & Aimere & 2.897 & 3.174 & 6.071 & 522 & 501 & 1.023 \\
\hline 2 & Bajawa & $\begin{array}{r}11.47 \\
7\end{array}$ & 12.564 & 24.041 & 1.728 & 1.659 & 3.387 \\
\hline 3 & $\begin{array}{l}\text { Bajawa } \\
\text { Utara }\end{array}$ & 2.655 & 2.928 & 5.583 & 447 & 459 & 906 \\
\hline 4 & Golewa & 5.142 & 5.677 & 10.819 & 805 & 751 & 1.556 \\
\hline 5 & $\begin{array}{l}\text { Golewa } \\
\text { Barat }\end{array}$ & 3.162 & 3.510 & 6.672 & 521 & 483 & 1.004 \\
\hline 6 & $\begin{array}{l}\text { Golewa } \\
\text { Selatan }\end{array}$ & 3.408 & 3.852 & 7.260 & 498 & 491 & 989 \\
\hline 7 & Inerie & 2.138 & 2.687 & 4.825 & 318 & 292 & 610 \\
\hline 8 & Jerebu'u & 1.754 & 2.171 & 3.925 & 199 & 199 & 398 \\
\hline 9 & Riung & 4.459 & 4.801 & 9.260 & 598 & 547 & 1.145 \\
\hline 10 & $\begin{array}{l}\text { Riung } \\
\text { Barat }\end{array}$ & 2.516 & 2.550 & 5.066 & 340 & 292 & 632 \\
\hline 11 & Soa & 3.978 & 4.317 & 8.295 & 549 & 517 & 1.066 \\
\hline 12 & Wolomeze & 1.625 & 1.657 & 3.282 & 222 & 166 & 388 \\
\hline & Total & 45.211 & 46.714 & 95.099 & 6.747 & 6.357 & 13.104 \\
\hline
\end{tabular}

Sumber: Data KPU Kabupaten Ngada Tahun 2015

Penelitian ini mengkaji perilaku memilih pemula Kabupaten Ngada pada saat penyelenggaraan Pilkada kabupaten Ngada tahun 2015. Identifikasi partai, orientasi terhadap isu dan orientasi terhadap calon merupakan pendekatan yang menerangkan perilaku memilih. ${ }^{5}$ Identifikasi partai merupakan dorongan untuk menjadi identik atau sama menerangkan bahwa sebuah partai akan memperoleh dukungan yang penuh dari pendukungnya apabila partai tersebut sudah semakin sukses dan solid. Begitupun sebaliknya apabila partai tersebut dinilai negatif

${ }^{5}$ Dieter Roth, Studi Pemilu Empiris Sumber, Teori-Teori, Instrumen dan Metode(Jakarta:Friedrich-Naumann-Stiftung für die freiheit, 2008) hal. 23 
maka pendukungnya akan meninggalkannya.Orientasi terhadap calon menerangkan citra positif harus melekat dalam diri calon tersebut, performa dan rekam kariernya menentukan keberhasilan calon tersebut. Orientasi terhadap isu, menjelaskan kemampuan partai dalam menyampaikan isu-isu kampanye.

Penelitian ini menjadi penting untuk diteliti dengan melihat perilaku memilih pemula melalui teori Hugh A bone dan Austin Ranney yang menyatakan bahwa, identtifikasi partai, orientasi calon, orientasi isu merupakan determinan dari perilaku memilih seseorang. Berdasarkan permasalahan di atas maka pada tulisan ini akan dibahas adalah seberapa besar pengaruh Identifikasi Partai terhadap perilaku memilih pemula kabupaten Ngada Tahun 2015? Seberapa besar pengaruh orientasi calon terhadap perilaku memilih pemula kabupaten Ngada? Seberapa besar pengaruh orientasi isu terhadap perilaku memilih pemula kabupaten Ngada?

\section{Metode}

Penelitian ini menggunakan metode survei dengan pendekatan kuantitatif deskriptif dan explanatory, karena tdak hanya menggambarkan atau mendeskripsikan fakta-fakta empiris yang ada dilapangan tetapi juga menganalisa seberapa besar pengaruh antara variabel yang atu dengan yang lain. Pendekatan kuantitatif deskriptif dan explanatory dilaksanakan guna memperoleh gambaran yang lengkap dalam mengkaji perilaku memilih pemula dalam Pemilihan kepala daerah kabupaten Ngada tahun 2015. Objek dari penelitian ini adalah perilaku memilih pemula yang pada Pilkada kabupaten Ngada tahun 2015 berusia 17-21 tahun.

Jenis data yang digunakan dalam penelitian ini data primer yang berasal dari jawaban responden terhadap kuesioner. Penelitian ini menggunakan analisis data dan intepretasinya yang akan digunakan untuk menjawab pertanyaan - pertanyaan penelitian untuk mengungkap fenomena sosial tertentu. Sehingga analisa data adalah proses penyederhanaan data ke dalam bentuk

Jurnal TAPIs Vol. 14 No.02 Juli-Desember 2018 
yang lebih mudah dibaca dan diinterpretasikan. Model yang akan digunakan dalam penelitian ini adalah model kausalitas atau hubungan atau pengaruh dan untuk menguji hipotesis yang diajukan, maka teknik analisis yang digunakan adalah Structural Equation Modelling (SEM) dari paket statistik LISREL.

\section{Pembahasan}

Surbakti berpendapat perilaku memilih adalah keikutsertaan waga negara dalam pemilihan umum merupakan serangkaian kegiatan membuat keputusan, yakni apakah memilih atau tidak memilih dalam pemilihan umum. Secara umum perilaku memilih merupakan tindakan atau sikap setiap warga negara yag terdaftar dalam daftar pemilih tetap (DPT) dan memberikan hak suaranya untuk memilih wakil-wakil yang dipercayai untuk memipin daerahnya. ${ }^{6}$ Model pendekatan perilaku memilih secara ringkas dapat diuraikan kedalam tiga pendekatan teori perilaku memilih yakni dalam meneliti perilaku memilih seseorang yakni model sosiologi, psikologi, dan rasional $^{7}$

Pendekatan sosiologi atau yang lebih dikenal Mazhab Colombia menurut Rooth,teori ini mengungkapkan determenesi perilaku memilih seseorang dipengaruhi oleh status sosila ekonomis, agama, dan daerah tempat tinggal seseorang. ${ }^{8}$ Sejalan dengan pendapat Affan Gafar preferensi pilihan pemilih berdasarkan pada karakteristik sosial individu yang bersangkutan. Penganut pendekatan ini lebih mengutamakan ikatan sosial dalam menentukan perilaku memilihnya. Ikatan sosial tersebut berupa, adanya persamaan dari segi etnik, ras, agama, keluarga, pertemanan yang dialami individu secara historis. ${ }^{9}$

${ }^{6}$ Ramlan Surbakti, Memahami Ilmu Politik (Jakarta: PT. Gramedia Widiasarana,1992)hal. 145

${ }^{7}$ Leo Agustino dan Muhamad Agus Yusoff,Kajian Politik dan Masalah Pembangunan (Jurnal Politik Volume V No I, 2009) hal.422

${ }^{8}$ Ibid 22-25

${ }^{9}$ Affan Gafar, Javanese Voters (Yokyakarta : Gajah Mada University Press, 1992) hal.43

Jurnal TAPIs Vol. 14 No.02 Juli-Desember 2018 
Pendekatan psikologis atau Michigan. Faktor psikologis mempengaruhi perilaku memilih seseorang. Pendektan psikologis menerangkan faktor jangka panjang maupun jangka pendek yang mempengaruhi perilaku memilih adalah identifikasi partai, orientasi calon dan orientasi isu yang dikenal sebagai trias determinan, perilaku memilih seseorang tidak serta merta muncul tetapi mengalami proses jangka waktu yang panjang sampai pada keputusan akhirnya untuk menjatuhkan keputusan memilih pada salah satu partai, proses sosialisasi ini biasanya terjadi pada lingkungan keluarga inti. Perilaku memilih pendekatan ini dapat diukur melalui identifikasi partai dengan cara melihat presepsi dan penilaian terhadap pasangan calon dan tema yang diusung ${ }^{10}$. Identifikasi partai merupakan hasil dari ikatan yang dibentuk melalui pengalaman proses sosialisasi untuk menjadi identik atau sama dengan partai tertentu. Orientasi calon, apabila pemilih semakin mengenal dan merasa cocok dengan kanidat atau partai tertentu maka kemungkinan besar pemilih akan memilih partai atau kanidat tertentu ${ }^{18}$. Orientasi isu merupakan tema-tema yang dianggap penting merupakan tawaran solusi dari partai atau kandidat tertentu dirasa sesuai dengan cara pandangnya, memungkinkannya untuk ikut memilih. ${ }^{12}$

Pendekatan Rasional atau Rational Choice, pendekatan ini melihat perilaku memilih berdasarkan atas pemikiran yang rasional, memilih berdasarkan pada asas manfaat untuk dirinya. Dari sudut pandang pemilih rasional mereka menghitung bagaimana memperleh keuntungan yang lebih tanpa harus mengeluarkan biaya yang besar. Dalam sudut pandang ekonomipolitik, pemilih rasional, individu sebagai warga tidak akan ikut memilih jika lebih menguntungkan bagi mereka karena mereka

\footnotetext{
${ }^{10}$ Dieter Roth, Studi Pemilu Empiris Sumber, Teori-Teori, Instrumen dan Metode(Jakarta:Friedrich-Naumann-Stiftung für die freiheit, 2008) hal. 37-38

${ }^{11}$ Adman Nursal, Political Marketing Strategi Memenangkan Pemilu sebuah Pendekatan Baru Kampanye Pemilihan DPRD, DPD, Presiden (Jakarta : PT Gramedia Pustaka Utama, 2004) hal. 59-60

${ }^{12}$ Dieter Roth, Studi Pemilu Empiris Sumber, Teori-Teori, Instrumen dan Metode(Jakarta:Friedrich-Naumann-Stiftung für die freiheit, 2008) hal. 41-42
}

Jurnal TAPIs Vol. 14 No.02 Juli-Desember 2018 
akan menikmati hasil yang sama dengan mereka yang memilih tanpa harus mengorbankan waktu dan tenaga untuk ikut memilih. Selain itu menurut Key ${ }^{13}$ pemilih lebih menentukan pilihannya secara prospektif, yaitu dengan melihat kinerja dari pemerintah yang berkuasa yang sudah berakhir mampu memberikan dampak yang positif bagi dirinya dan pemerintahan sehingga akan dipilih kembali pada pemilu berikutnya sebaliknya apabila pemerintah tidak memberikan dampak yang positif bagi dirinya dan pemerintahan maka akan ditinggalkan dan tidak akan dipilih lagi pada pemilu selanjutnya. Keputusan untuk memilih pada pemilihan umum lebih ditentukan pada sejumlah prestasi yang sudah diukir dari pemerintah pada saat berkuasa.

\section{Krakteritisk Responden}

\section{a. Berdasarkan Jenis Kelamin}

Gambar 1.

Krakteristik Responden Berdasarkan Jenis Kelamin

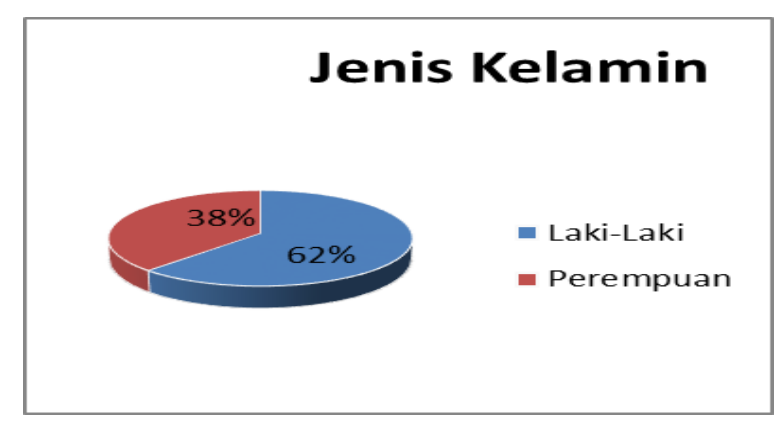

Sumber: olah data 2018

${ }^{13}$ Ibid,hal. 48-49 
Gambar di atas menunjukan bahwa responden berjenis kelamin laki-laki lebih besar (62\%) dari responden berjenis kelamin perempuan, artinya data di atas menunjukan mayoritas responden berasal dari responden berjenis kelamin laki-laki.

\section{b. Berdasarkan usia}

Dalam tulisan ini penulis mengelompokan krakteristik pemilih pemula kabupaten Ngada berdasarkan usia 17-21 tahun, yakni usia minimum dalam mengikuti pemilihan umum.

\section{c. Berdasarkan Pendidikan terkahir}

Gambar 2

Krakteritik RespondenBerdasarkan Pendidikan Terakhir

\section{Pendidikan Terakhir}

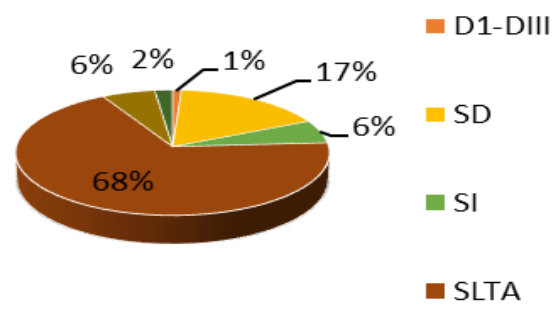

Sumber: olah data 2018

Dari gambar di atas dapat menunjukan responden yang menempati urutan pertama yakni SLTA dengan presentase $68 \%$, urutan kedua adalah SD,17\%, selanjutnya SLTP dan S1 masingmasing, 6\%, selanjutnya D1-D3, 1\% dan tidak menyelesaikan pendidikan SD 2\%. Hal ini menunjukan bahwa mayoritas responden pendidikan terkahirnya adalah SMA.

\section{d. Berdasarkan Pekerjaan}


Gambar 3

Krakteritik Responden Berdasarkan Pendidikan Terakhir

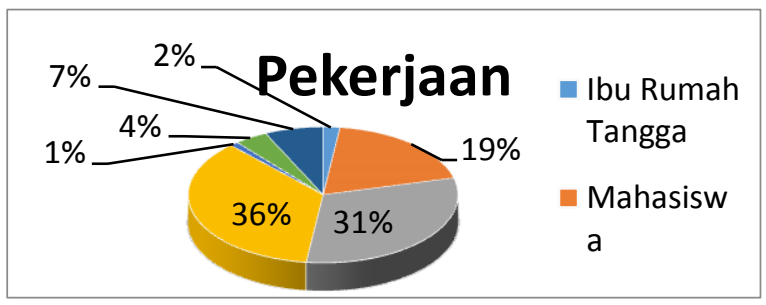

Sumber: Hasil Olahan Peneliti, 2018.

Dari gambar diatas dapat menunjukan responden berdasarkan pekerjaan yang menempati urutan pertama petani dengan presentase $36 \%$, urutan kedua adalah pelajar, $31 \%$, mahasiswa, $19 \%$, wirasaswasta, $7 \%$, tidak memiliki pekerjaan $4 \%$, ibu rumah tangga $2 \%$, dan sopir, $1 \%$. Hal ini menunjukan bahwa mayoritas responden memiliki peerjaan sebagai petani.

\section{Uji Validitas}

Penelitian ini menggunakan uji validitas dari Structral Equation Modelling (SEM). Setiap indikator dapat dikatakan valid apabila indikator-indikator harus berada pada level signifikan yakni, 0.05 atau 0.01(t-vale > 1.96, alpa 0.05 dan 2.75 untuk alpha 0.01) atau standar loading factor (SLF) $\geq 0.50 .^{14}$ Berdasarkan hasil olah data pada butir pernyataan tabel uji pernyataan-pernyataan tersebut dinyatakan valid.

\footnotetext{
${ }^{14}$ Hendryadi dan Suryani. Structural Equation Modeling Dengan Lisrel 8.80 Pedoman Untuk Pemula (Yokyakarta: Kaukaba Dipantara, 2014) hal. 17
}

Jurnal TAPIs Vol. 14 No.02 Juli-Desember 2018 
Yohana Apaut, dkk: FAKTOR-FAKTOR YANG

Tabel 2 Uji Validitas

\begin{tabular}{|c|c|c|c|c|}
\hline Variabel & Item & $\begin{array}{l}\text { Koefisien } \\
\text { Validitas } \\
\text { SLF }\end{array}$ & $\begin{array}{l}\text { Standart } \\
\text { Nilai SLF }\end{array}$ & Keterangan \\
\hline \multirow{4}{*}{$\begin{array}{l}\text { Identifikasi } \\
\text { partai (X1) }\end{array}$} & $\mathrm{P} 1$ & 0.632 & 0.5 & Valid \\
\hline & $\mathrm{P} 2$ & 0.851 & 0.5 & Valid \\
\hline & P3 & 0.761 & 0.5 & Valid \\
\hline & $\mathrm{P} 4$ & 0.819 & 0.5 & Valid \\
\hline \multirow{9}{*}{$\begin{array}{c}\text { Orientasi } \\
\text { calon (X2) }\end{array}$} & P5 & 0.801 & 0.5 & Valid \\
\hline & P6 & 0.760 & 0.5 & Valid \\
\hline & P7 & 0.815 & 0.5 & Valid \\
\hline & P8 & 0.780 & 0.5 & Valid \\
\hline & P9 & 0.890 & 0.5 & Valid \\
\hline & P10 & 0.829 & 0,5 & Valid \\
\hline & P11 & 0.629 & 0.5 & Valid \\
\hline & P12 & 0.676 & 0.5 & Valid \\
\hline & P13 & 0.896 & 0.5 & Valid \\
\hline \multirow{7}{*}{$\begin{array}{l}\text { Orientasi isu } \\
\text { (X3) }\end{array}$} & P14 & 0.613 & 0.5 & Valid \\
\hline & P15 & 0.617 & 0.5 & Valid \\
\hline & P16 & 0.629 & 0.5 & Valid \\
\hline & P17 & 0.774 & 0.5 & Valid \\
\hline & P18 & 0.878 & 0.5 & Valid \\
\hline & P19 & 0.937 & 0.5 & Valid \\
\hline & P20 & 0.749 & 0.5 & Valid \\
\hline \multirow{3}{*}{$\begin{array}{c}\text { Perilaku } \\
\text { memilih (Y) }\end{array}$} & $\mathrm{P} 21$ & 0.810 & 0.5 & Valid \\
\hline & $\mathrm{P} 22$ & 0.906 & 0.5 & Valid \\
\hline & P23 & 0.771 & 0.5 & Valid \\
\hline
\end{tabular}

Sumber: hasil olah data peneliti, 2018 


\section{Uji Reabilitas}

Reabilitas dalam penelitian ini menggunkan Structral Equation Modelling (SEM) dengan nilai construct reability (CR) 0.7 dan nilai variance extracted (VE) 0.5, menggunakan rumus sebagai berikut:

$$
\text { Construct Reliability }=\frac{\left(\sum \text { Standardized Loading }\right)^{2}}{\left(\sum \text { Standardized Loading }\right)^{2}+\left(\sum \text { Measurement Error }\right)}
$$

Kemudian mencari nilai variance extracted (VE) dengan rumus sebagi berikut:

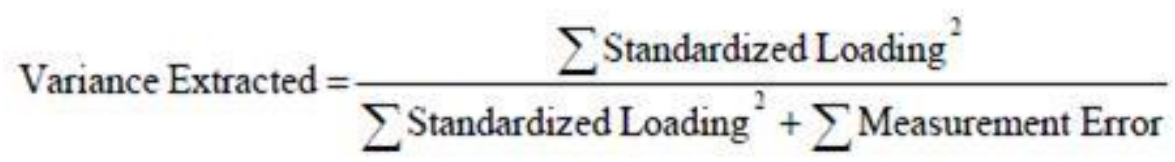

Berdasarkan rumus (CR) dan (VE) maka variabel tersebut dinyatakan reabilitas,

Tabel 3.

Uji Reliabilitas Variabel Identifikasi Partai $\left(\mathrm{X}_{1}\right)$

\begin{tabular}{|c|c|c|c|c|c|c|c|}
\hline $\begin{array}{c}\text { Laten } \\
\text { Variabel }\end{array}$ & $\begin{array}{c}\text { Observed } \\
\text { Variabel }\end{array}$ & SLF & SLF`2 $^{\wedge}$ & Error & CR & VE & Keterangan \\
\hline \multirow{3}{*}{$\begin{array}{c}\text { Identifikasi } \\
\text { Partai (X1) }\end{array}$} & $\mathrm{X} 1.1$ & 0.632 & 0.399 & 0.601 & & & Realiabel \\
\cline { 2 - 5 } & $\mathrm{X} 1.2$ & 0.851 & 0.724 & 0.276 & \multirow{2}{*}{0.852} & \multirow{2}{*}{0.593} & Realiabel \\
\cline { 2 - 5 } \cline { 3 - 5 } & $\mathrm{X} 1.3$ & 0.761 & 0.579 & 0.421 & & & Realiabel \\
\hline Orientasi & $\mathrm{X} 2.1$ & 0.819 & 0.671 & 0.329 & & & Realiabel \\
\hline
\end{tabular}


Yohana Apaut, dkk: FAKTOR-FAKTOR YANG

\begin{tabular}{|c|c|c|c|c|c|c|c|}
\hline $\begin{array}{c}\text { Laten } \\
\text { Variabel }\end{array}$ & $\begin{array}{l}\text { Observed } \\
\text { Variabel }\end{array}$ & SLF & $\mathrm{SLF}^{\wedge} 2$ & Error & CR & VE & Keterangan \\
\hline \multirow[t]{8}{*}{ Calon (X2) } & $\mathrm{X} 2.2$ & 0.760 & 0.578 & 0.422 & & & Realiabel \\
\hline & $\mathrm{X} 2.3$ & 0.815 & 0.664 & 0.336 & & & Realiabel \\
\hline & $\mathrm{X} 2.4$ & 0.780 & 0.608 & 0.392 & & & Realiabel \\
\hline & $\mathrm{X} 2.5$ & 0.890 & 0.792 & 0.208 & & & Realiabel \\
\hline & $\mathrm{X} 2.6$ & 0.829 & 0.687 & 0.313 & & & Realiabel \\
\hline & $\mathrm{X} 2.7$ & 0.892 & 0.796 & 0.204 & & & Realiabel \\
\hline & $\mathrm{X} 2.8$ & 0.676 & 0.457 & 0.543 & & & Realiabel \\
\hline & $\mathrm{X} 2.9$ & 0.896 & 0.803 & 0.197 & & & Realiabel \\
\hline \multirow{5}{*}{$\begin{array}{l}\text { Orientasi } \\
\text { Isu(X3) }\end{array}$} & X3.1 & 0.613 & 0.376 & 0.624 & \multirow{5}{*}{0.899} & \multirow{5}{*}{0.566} & Realiabel \\
\hline & $\mathrm{X} 3.2$ & 0.617 & 0.381 & 0.619 & & & Realiabel \\
\hline & X3.3 & 0.629 & 0.396 & 0.604 & & & Realiabel \\
\hline & X3.4 & 0.774 & 0.599 & 0.401 & & & Realiabel \\
\hline & $\mathrm{X} 3.5$ & 0.878 & 0.771 & 0.229 & & & Realiabel \\
\hline \multirow{5}{*}{$\begin{array}{l}\text { Perilaku } \\
\text { memilih } \\
(\mathrm{Y})\end{array}$} & X3.6 & 0.937 & 0.878 & 0.122 & & & Realiabel \\
\hline & X3.7 & 0.749 & 0.561 & 0.439 & & & Realiabel \\
\hline & Y.1 & 0.810 & 0.656 & 0.344 & \multirow{3}{*}{0.869} & \multirow{3}{*}{0.690} & Realiabel \\
\hline & Y.2 & 0.906 & 0.821 & 0.179 & & & Realiabel \\
\hline & Y.3 & 0.771 & 0.594 & 0.406 & & & Realiabel \\
\hline
\end{tabular}

Sumber: olah data peneliti, 2018.

\section{Uji Normalitas}

Uji Normalitas menggunakan aplikasi Lisreal dengan membandingkan nilai skewness dan kurotsis. Dikatakan baik apabila skewness $<2$ dan kurtosis $<7$. Distribusi normal apabila pvalue skewness dan kurtosis $\geq 0.05 .{ }^{15}$ Uji normatis dari penelitian ini dikatakan bagus, dapat dilihat pada tabel berikut:

Tabel 4

Uji Normalitas

\begin{tabular}{|ccc|}
\hline \multicolumn{2}{|c|}{ Test of Univariate Normality for Continuous Variables } \\
\hline Skewness & Kurtosis & $\begin{array}{c}\text { Skewness and } \\
\text { Kurtosis }\end{array}$ \\
\hline
\end{tabular}

${ }^{15}$ Haryadi Sarjono dan Winda Julianita, Spss vs Lisrel Sebuah Pengantar Aplikasi Untuk Riset (Jakarta: Salemba Empat, 2013)hal. 58

Jurnal TAPIs Vol. 14 No.02 Juli-Desember 2018 
Yohana Apaut, dkk: FAKTOR-FAKTOR YANG

\begin{tabular}{|c|c|c|c|c|c|c|}
\hline Variabel & $\begin{array}{c}\text { Z- } \\
\text { Score }\end{array}$ & $\begin{array}{c}\text { P- } \\
\text { Value }\end{array}$ & $\begin{array}{c}\text { Z- } \\
\text { scroe }\end{array}$ & $\begin{array}{c}\text { P- } \\
\text { Value }\end{array}$ & $\begin{array}{c}\text { Chi- } \\
\text { Square }\end{array}$ & $\begin{array}{c}\text { P- } \\
\text { Value }\end{array}$ \\
\hline X1.1 & -0.893 & 0.372 & 0.230 & 0.818 & 0.851 & 0.653 \\
\hline $\mathrm{X} 1.2$ & -1.047 & 0.295 & 0.398 & 0.690 & 1.255 & 0.534 \\
\hline X1.3 & -0.789 & 0.430 & 0.263 & 0.793 & 0.691 & 0.708 \\
\hline X1.4 & -0.893 & 0.403 & 0.412 & 0.680 & 0.869 & 0.648 \\
\hline X2.1 & -0.692 & 0.489 & $0 . \overline{288}$ & 0.774 & 0.561 & 0.755 \\
\hline $\mathrm{X} 2.2$ & -0.195 & 0.845 & 1.203 & 0.229 & 1.486 & 0.476 \\
\hline $\mathrm{X} 2.3$ & -0.850 & 0.395 & 0.392 & 0.695 & 0.877 & 0.645 \\
\hline $\mathrm{X} 2.4$ & -0.837 & 0.403 & 0.425 & 0.671 & 0.881 & 0.644 \\
\hline $\mathrm{X} 2.5$ & -0.445 & 0.656 & 1.326 & 0.185 & 1.957 & 0.376 \\
\hline $\mathrm{X} 2.6$ & -0.888 & 0.375 & 0.324 & 0.746 & 0.893 & 0.640 \\
\hline X2.7 & -0.100 & 0.920 & $1 . \overline{282}$ & 0.200 & 1.654 & 0.437 \\
\hline X2.8 & -0.412 & 0.680 & $\begin{array}{c}- \\
1.040\end{array}$ & 0.299 & 1.250 & 0.535 \\
\hline $\mathrm{X} 2.9$ & -0.489 & 0.625 & 1.089 & 0.276 & 1.426 & 0.490 \\
\hline $\mathrm{X} 3.1$ & -1.089 & 0.276 & 0.367 & 0.713 & 1.321 & 0.628 \\
\hline X3.2 & -1.002 & 0.316 & 0.097 & 0.922 & 1.014 & 0.602 \\
\hline X3.3 & -0.864 & 0.387 & 0.349 & 0.727 & 0.869 & 0.648 \\
\hline X3.4 & -0.749 & 0.454 & 0.127 & 0.899 & 0.577 & 0.749 \\
\hline X3.5 & -0.872 & 0.383 & 0.177 & 0.860 & 0.791 & 0.673 \\
\hline X3.6 & -0.104 & 0.298 & $0 . \overline{503}$ & 0.615 & 1.336 & 0.513 \\
\hline X3.7 & -0.238 & 0.216 & 0.422 & 0.673 & 1.709 & 0.425 \\
\hline Y.1 & -0.920 & 0.358 & 0.616 & 0.538 & 1.225 & 0.542 \\
\hline Y.2 & -0.863 & 0.388 & 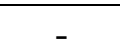 & 0.660 & 0.938 & 0.626 \\
\hline
\end{tabular}

Jurnal TAPIs Vol. 14 No.02 Juli-Desember 2018 
Yohana Apaut, dkk: FAKTOR-FAKTOR YANG

\begin{tabular}{|ccccccc|}
\hline \multicolumn{8}{|c}{ Test of Univariate Normality for Continuous Variables } \\
\hline & \multicolumn{2}{c|}{ Skewness } & \multicolumn{2}{c|}{ Kurtosis } & \multicolumn{2}{c|}{$\begin{array}{c}\text { Skewness and } \\
\text { Kurtosis }\end{array}$} \\
\hline Variabel & $\begin{array}{c}\text { Z- } \\
\text { Score }\end{array}$ & $\begin{array}{c}\text { P- } \\
\text { Value }\end{array}$ & $\begin{array}{c}\text { Z- } \\
\text { scroe }\end{array}$ & $\begin{array}{c}\text { P- } \\
\text { Value }\end{array}$ & $\begin{array}{c}\text { Chi- } \\
\text { Square }\end{array}$ & $\begin{array}{c}\text { P- } \\
\text { Value }\end{array}$ \\
\hline & & & 0.440 & & & \\
\hline & & & - & & & \\
Y.3 & -1.014 & 0.310 & 0.494 & 0.621 & 1.273 & 0.529 \\
\hline
\end{tabular}

Sumber: Hasil olah data peneliti,2018.

\title{
Uji Hipotesis
}

\section{Pengujian Hipotesis I}

HO: $\gamma 1=0$ : Identifikasi Partai $\left(\mathrm{X}_{1}\right) \quad(\xi 1)$ tidak berpengaruh signifikan terhadap

Perilaku Memilih Pemula (Y) ( $\eta)$

\author{
$H 1: \gamma 1 \neq 0$ : Identifikasi Partai $\left(\mathrm{X}_{1}\right) \quad(\xi 1)$ berpengaruh \\ signifikan terhadap \\ Perilaku Memilih Pemula (Y) ( $\eta)$
}

Nilai koefisien jalur identifikasi partai sebesar 0.406 dengan t-hitungnya $3.173>$ dari t-tabel 1.1986 dengan tingkat keyakinan 95\% $(\alpha=0.05)$ maka diputuskan menolak H0 sehingga Hipotesis 1 diterima, artinya variabel identifikasi partai (X1) berpengaruh signifkan terhadap perilaku memilih pemula (Y). Koefisien jalur 0.406 menunjukan bahwa adanya hubungan positif antara identifikasi partai terhadap perilaku memilih pemula, maksudnya adanya tingkat kepercayaan yang tinggi pemilih pemula terhadap identifikasi partai yang diikuti meningkatnya perilaku memimilih pemula pada pelaksanaan pilkada Kabupaten Ngada Tahun 2015.

Responden memiliki kepercayaan yang tinggi terhadap partai politik sebagai partai pengusung kandidat peserta Pilkada Kabupaten Ngada Tahun 2015, sikap loyal responden tehadap

Jurnal TAPIs Vol. 14 No.02 Juli-Desember 2018 
partai diwujudkan dengan tindakan nyata dengan memilih kandidat sesuai dengan partai yang diusungnya.

\section{Pengujian Hipotesis 2}

$H O: \gamma 2=0$ : Orientasi Calon $\left(X_{2}\right) \quad(\xi 2)$ tidak berpengaruh signifikan terhadap Perilaku Memilih Pemula (Y) ( $\eta)$

$H 1: \gamma 2 \neq 0 \quad$ :Orientasi Calon $\left(X_{2}\right)(\xi 2)$ berpengaruh signifikan terhadap Perilaku Memilih Pemula $(Y)(\eta)$

Nilai koefisien jalur Orientasi calon sebesar 0.349 dengan t-hitungnya $3.084>$ dari t-tabel 1.1986 dengan tingkat keyakinan 95\% $(\alpha=0.05)$ maka diputuskan menolak H0 sehingga Hipotesis 2 diterima, artinya variabel orientasi calon (X2) berpengaruh signifkan terhadap perilaku memilih pemula (Y). Koefisien jalur 0.349 menunjukan bahwa adanya hubungan positif antara orientasi calon terhadap perilaku memilih pemula, maksudnya adanya tingkat kepercayaan yang tinggi pemilih pemula terhadap orientasi calon yang diikuti meningkatnya perilaku memilih pemula pada pelaksanaan pilkada Kabupaten Ngada Tahun 2015.

Kepercayaan responden terhadap kandidat sebagai peserta pilkada Kabupaten Ngada tahun 2015 yang memiliki rekam jejak yang baik, keperibadian yang serta memiliki kharisma kepemimpinan mempengaruhi keputusan responden untuk memilih kepada kandidat mana hak suaranya diberi yang diwujud nyatakan dalam mengikuti dan memberikan hak suaranya di TPS(Tempat Pemungutan Suara) pada Pelaksanaan Pilkada Kabupaten Ngada Tahun 2015.

\section{Pengujian Hipotesis 3}

HO: $\gamma 3=0$ : Orientasi Isu $\left(X_{3}\right)$ ( $\left.\xi 3\right)$ tidak berpengaruh signifikan terhadap Perilaku Memilih Pemula $(Y)$ (ๆ) 
H1: $\gamma 3 \neq 0$ : Orientasi Isu $\left(X_{3}\right)$ ( $\left.\xi 3\right)$ berpengaruh signifikan terhadap Perilaku Memilih Pemula $(Y)(\eta)$

Nilai koefisien jalur Orientasi isu sebesar 0.259 dengan thitungnya $2.816>$ dari t-tabel 1.1986 dengan tingkat keyakinan 95\% $(\alpha=0.05)$ maka diputuskan menolak H0 sehingga Hipotesis 3 diterima, artinya variabel orientasi isu (X2) berpengaruh signifikan terhadap perilaku memilih pemula (Y). Koefisien jalur 0.259 menunjukan bahwa adanya hubungan positif antara identifikasi partai terhadap perilaku memilih pemula, maksudnya adanya tingkat kepercayaan yang tinggi responden terhadap orientasi isu, diikuti meningkatnya perilaku memilih pemula pada pelaksanaan pilkada Kabupaten Ngada Tahun 2015.

Responden memiliki kepercayaan yang tinggi terhadap isu-isu yang ditawarkan oleh kandidat peserta Pilkada Kabupaten Ngada Tahun 2015, mereka meyakini akan isu-isu yang ditawarkan seperti isu ekonomi, kesehatan, isu pendidikan, isu sosial merupakan isu yang penting dan sesuai dengan apa yang menjadi keinginan responden. Sikap meyakini dan percaya terhadap isu -isu yang ditawarkan loyal diwujudkan dengan tindakan nyata dengan memilih kandidat yang menawarkan isuisu tersebut pada pelakanaan pilkada Kabupaten Ngada Tahun 2015.

\section{Pengujian Hipotesis 4}

HO: $\gamma 4=0$ : Identifikasi Partai $\left(X_{1}\right)$, Orientasi Calon $\left(X_{2}\right)$ dan Orientasi Isu $\left(X_{3}\right)$ tidak berpengaruh signifikan terhadap Perilaku Memilih Pemula $(Y)$

H1: $\gamma 4 \neq 0$ : Identifikasi Partai $\left(X_{1}\right)$, Orientasi Calon $\left(X_{2}\right)$ dan Orientasi Isu $\left(X_{3}\right)$ berpengaruh signifikan terhadap Perilaku Memilih Pemula (Y)

Variabel identifikasi partai (X1), Orientasi calon (X2), Orientasi isu( X3) berpengaruh signifikan terhadap variabel perilaku memilih pemula (Y) dengan menolak Ho dan Hipotesis 4 
diterima. Yang mana Uji $\mathrm{F}$ dalam penelitian ini dihitung secara manual. Adapun rumus uji $\mathrm{F}$ dapat dilihat di bawah ini:

$$
\begin{aligned}
F & =\frac{R^{2} / k}{\left(1-R^{2}\right) /(N-k-1)} \\
F & =\frac{0.796 / 3}{(1-0.796) /(100-3-1)} \\
F & =126.123
\end{aligned}
$$

Dari tabel diatas dapat dilihat nilai $\mathrm{F}_{\text {hitung }}$ sebesar 126.123 lebih besar dibanding $F_{\text {tabel }}$ sebesar 1.986 dengan derajat keyakinan 95\% ( $\alpha=0.05)$ maka diputuskan untuk menolak $\mathrm{H}_{0}$ sehingga $\mathrm{H}_{1}$ diterima. Artinya terdapat hubungan signifikan variabel identifikasi(X1), variabel orientasi calon $\left(\mathrm{X}_{2}\right)$ dan orientasi isu $\left(\mathrm{X}_{3}\right)$ partai terhadap variabel perilaku pemilih pemula(Y). Jadi berdasarkan hasil pengujian dapat disimpulkan : Identifikasi Partai $\left(\mathrm{X}_{1}\right)$, Orientasi Calon $\left(\mathrm{X}_{2}\right)$ dan Orientasi Isu $\left(\mathrm{X}_{3}\right)$ secara simultan berpengaruh signifikan terhadap Perilaku Memilih Pemula (Y). Sehingga dapat digambarkan model pesamaan yang diperoleh:

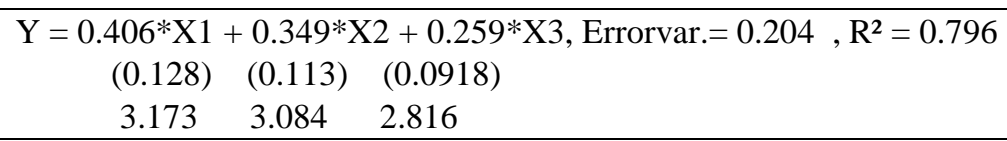

Dari persamaan di atas menunjukan bahwa gabungan pengaruh yang diberikan oleh Identifikasi Partai $\left(\mathrm{X}_{1}\right)$, Orientasi Calon $\left(\mathrm{X}_{2}\right)$, dan Orientasi Isu $\left(\mathrm{X}_{3}\right)$ Perilaku Memilih Pemula (Y) yaitu sebesar nilai $\mathrm{R} 2=0,796$ yang berarti bahwa besarnya pengaruh Identifikasi Partai $\left(\mathrm{X}_{1}\right)$, Orientasi Calon $\left(\mathrm{X}_{2}\right)$, dan Orientasi Isu $\left(\mathrm{X}_{3}\right)$ adalah sebesar $79.6 \%$ dengan varians kesalahan (error variance) sebesar 0.204. Dengan kata lain, angka ini juga menunjukan bahwa identifikasi partai $\left(\mathrm{X}_{1}\right)$, orientasi calon $\left(\mathrm{X}_{2}\right)$, dan orientasi isu $\left(\mathrm{X}_{3}\right)$ dapat menjelaskan $79.6 \%$ 
varian perilaku memilih pemula (Y), sedangkan 20.4\% lainnya dijelaskan oleh faktor lain yang tidak diteliti dalam model.

Besaran pengaruh variabel Identifikasi Partai, Orientasi Calon, Orientasi Isu terhadap perilaku memilih pemula kabupaten Ngada pada Pilkada 2015

\section{Nilai Koefisien Variabel}

Untuk mencari Nilai koefisien masing-masing variabel dilakukan dengan menggunakan model struktural (standardized solution)

Gambar 4

Model Structural (Standardized Solution)

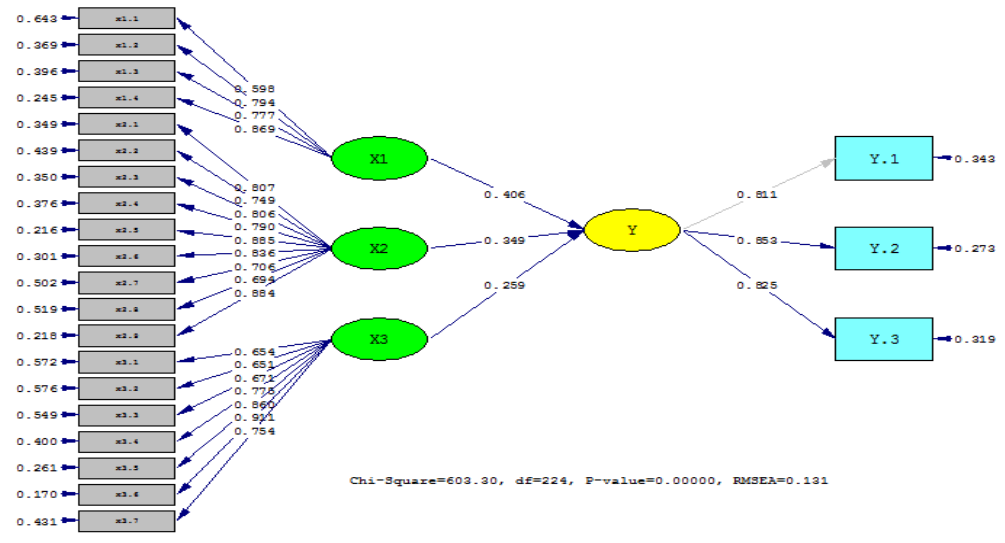

Sumber: hasil estimasi SEM,2018. 
Nilai koefisien dari variabel identifikasi partai (X1) terhadap variabel perilaku memimilih pemula (Y) sebesar 0.406 , orientasi calon (X2) terhadap variabel perilaku memilih pemula (Y) sebesar 0.349 dan orientasi isu terhadap variabel perilaku memilih pemula (Y) sebesar 0.259, artinya hubungan ketiga variabel tersebut menunjukan hubungan yang postif dikarenakan nilai koefisien ketiga variabel tersebut yakni koefisien identfikasi partai 0.406 memiliki nilai yang lebih besar dari tingkat derajat keyakinan yakni $95 \%(\alpha=0.05)$, koefisien jalur orientasi calon 0.349 memiliki nilai yang lebih besar dari tingkat derajat keyakinan yakni $95 \%(\alpha=0.05)$, koefisien jalur orientasi isu sebesar 0.259 memiliki nilai yang lebih besar dari tingkat derajat keyakinan yakni $95 \%(\alpha=0.05)$. Nilai koefisien jalur lebih besar dari derajat keyakinan mengiindifikasikan bahwa responden memberikan nilai kepercayaan yang positif terhadap variabel identifikasi partai,orientasi calon, variabel orientasi isu dalam mempengaruhi keputusan untuk memilih pada pemilihan kepala daerah Kabupaten Ngada tahun 2015.

\section{T-hitung}

Dilakukan menggunakan estimasi SEM model struktural tvalue yang bertujuan untuk mencari nilai t, untuk dapat mengetahui dan mengukur besaran pengarung masing-masing variabel, dapat dilihat pada tampilan gambar berikut ini

Gambar 5

Model Struktural (t-value)

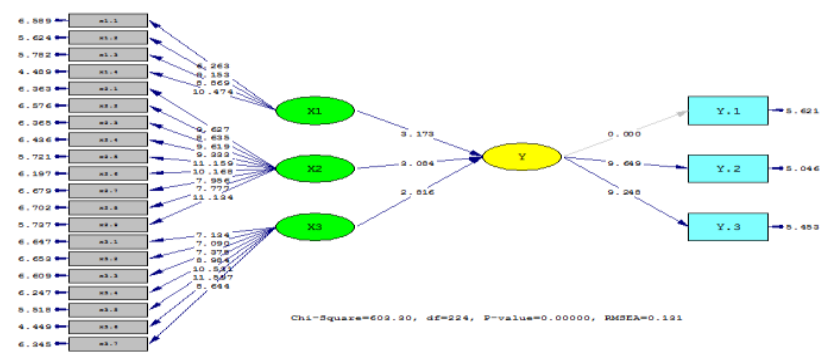


Sumber: Hasil Estimasi SEM, 2018.

Pada gambar ditunjukan bahwa nilai $t$-hitung identifikasi partai $\left(\mathrm{X}_{1}\right)$ terhadap perilaku memilih pemula $(\mathrm{Y})$ sebesar 3.173 sementara nilai orientasi calon $\left(\mathrm{X}_{2}\right)$ terhadap perilaku memilih pemula $(\mathrm{Y})$ sebesar 3.084, dan nilai orientasi isu $\left(\mathrm{X}_{3}\right)$ terhadap perilaku memilih pemula (Y) sebesar 2.816 .

Tabel 5

Besaran Pengaruh Variabel Ientifikasi Partai $\left(\mathrm{X}_{1}\right)$, Orientasi Calon $\left(\mathrm{X}_{2}\right)$ dan Orientasi Isu $\left(\mathrm{X}_{3}\right)$ Terhadap Perilaku Memilih Pemula (Y)

\begin{tabular}{|c|c|c|c|c|c|c|c|c|}
\hline \multirow{2}{*}{$\begin{array}{l}\text { Va } \\
\text { ria } \\
\text { bel }\end{array}$} & \multirow{2}{*}{$\begin{array}{c}\text { Koefis } \\
\text { ien } \\
\text { Jalur }\end{array}$} & \multirow{2}{*}{$\begin{array}{l}\text { Penga } \\
\text { ruh } \\
\text { Langs } \\
\text { ung }\end{array}$} & \multicolumn{3}{|c|}{$\begin{array}{c}\text { Pengaruh Tidak } \\
\text { Langsung }\end{array}$} & \multirow{2}{*}{$\begin{array}{c}\text { Total } \\
\text { Penga } \\
\text { ruh }\end{array}$} & \multirow{2}{*}{$\begin{array}{c}\text { Total } \\
\text { Pengar } \\
\text { uh } \%\end{array}$} & \multirow[t]{2}{*}{$\begin{array}{l}\text { Nilai T- } \\
\text { Hitung }\end{array}$} \\
\hline & & & X1 & $\mathrm{X} 2$ & X3 & & & \\
\hline $\mathrm{X} 1$ & 0.406 & 0.165 & & $\begin{array}{c}0.10 \\
6\end{array}$ & $\begin{array}{c}0.06 \\
5\end{array}$ & 0.336 & 33.6 & 3.173 \\
\hline $\mathrm{X} 2$ & 0.349 & 0.122 & $\begin{array}{l}0.1 \\
06 \\
\end{array}$ & & $\begin{array}{c}0.05 \\
0\end{array}$ & 0.277 & 27.7 & 3.084 \\
\hline X3 & 0.259 & 0.067 & $\begin{array}{r}0.0 \\
65 \\
\end{array}$ & $\begin{array}{c}0.05 \\
0 \\
\end{array}$ & & 0.182 & 18.2 & 2.816 \\
\hline & & Peng & h B & sama & Ima & 0.795 & 79.5 & \\
\hline
\end{tabular}

Sumber: Hasil Olah Data peneliti, 2018.

Tabel di atas menjelaskan bahwa identifikasi parti (X1) mempengaruh perilaku pemilih pemula (Y) sebesar 0.336 (33.6\%), orientasi calon (X2) mempengruhi perilaku pemilih pemula (Y) sebesar 0.277(27.7\%), orientasi isu (X3) mempengaruhi perilaku memilih pemula $(\mathrm{Y})$ sebesar $(0.795 \%)$ dengan total pengaruh bersama sama sebesar 0.795(79.5\%) dengan melihat t-hitung dari ketiga variabel di atas yakni variabel identifikasi t-hitung sebesar 3.173, variabel orientasi calon nilai thitung3.084 dan nilai dari t-hitung variabel orientasi isu sebesar 2.816 mengindifikasaikan variabel identifikasi partai (X1),

Jurnal TAPIs Vol. 14 No.02 Juli-Desember 2018 
variabel orientasi calon (X2) dan Variabel orientasi isu (X3) berpengaruh signifikan terhadap variabel perilaku memilih pemula (Y) karena memiliki t-hitung lebih besar dari t-value 1.986. artinya mayoritas pemilih pemula dalam pemilihan kepala daerah Kabupaten Ngada tahun 2015 dipengaruhi faktor identifikasi partai sebesar $33.6 \%$ lebih besar dari pengaruh faktor orientasi calon sebesar $27.7 \%$ dan faktor orientasi isu sebesar $18.2 \%$. Berarti pemilih pemula kabupaten Ngada dalam pemilihan kepala daerah tahun 2015 lebih mepercayai patai politik sebagai lembaga yang melahirkan kadar-kader politik yang berkualitas dan berintegritas.

Pemilih pemula mengetahui dan memahami peranan partai politik dalam pilkada serta meyakani bahwa wadah politik yang dipercayai melahirkan kader-kader politik yang berkualitas dapat mewakili aspirasi pemilih pemula dan bisa menjawab berbagai isu yang ada didalam masyarakat. Pengaruh faktor orientasi calon terhadap perilaku memilih pemula pada pemilihan kepala daerah Kabupaten Ngada sebesar $27.7 \%$ lebih rendah dari faktor identifikasi partai memiliki arti bahwa walaupun memiliki angka yang signifikan namun faktor orientasi calon masih lebih rendah pengaruhnya terhadap perilaku pemilih pemula untuk memutuskan kepada pasangan calon yang akan dipilih.

Hal ini mengindikasikan bahwa pemilih pemula kurang yakin akan pasangan calon yang dipilihnya memiliki profil, track record dan performa yang bisa mempengaruhi pilihan pemilih pemula karena kurang sesuai dengan apa yang diharapkan oleh pemilih pemula. Oleh karena itu pasangan calon sebagai peserta pemiliu sekira dapat meningkatkan performanya dengan cara lebih terlibat didalam kegiatan sosial didalam masyarakat dengan turun langsung ke masyarakat agar mudah diketahui dan dikenal masyarakat, lebih meningkatkan citra positifnya dengan lebih aktif dalam memberikan contoh yang positif terhadap masyarakat baik dalam kehidupan kelurganya yang terlihat harmonis, dan dalam kehidupannya sehari-harinya dengan menciptakan citra yang positif terhadap dirinya.

Jurnal TAPIs Vol. 14 No.02 Juli-Desember 2018 
Faktor orientasi isu mempengaruhi perilaku memilih pada pemilihan kepala daerah Kabupaten Ngada tahun 2015 sebesar $18.2 \%$, angka ini menujukan orientasi isu tidak teralu berpengaruh terhadap pertimbangan pemilih pemula dalam memutuskan pilihannya dipengaruhi oleh faktor orintasi isu, angka $18.2 \%$ memperlihatkan pengaruhnya terhadap perilaku memilih pemula tidak sebesar pengaruh faktor identifikasi partai maupun faktor orientasi calon, menunjukan bahwa pemilih pemula kurang meyakini isu-isu yang ada didalam masyarakat Kabupaten Ngada dapat menjawab berbagai persoalan yang terjadi didalam masyarakat kabupaten Ngada. Isu yang ditawarkan kepada masayarakat sekiranya dapat membawakan hasil perubahaan yang positif dalam kehidupan masyarakat Kabupaten Ngada isu yang ditawarkan pasangan calon pada saat kampanye melalui pemamparan visi misi.

\section{Penutup}

Berdasarkan hasil uji statistik yang telah dilakukan pada penelitian ini, maka hasil penelitian dapat disimpulkan bahwa:

1. Variabel Identifikasi Partai (X1) berpengaruh signifikan dengan variabel perilaku memilih pemula (Y), sebesar $33.6 \%$ dengan nilai koefisien jalur yang ditemukan sebesar 0,406 dan t-hitungnya sebesar 3.173. Identifikasi parati sangat mempengaruhi perilaku memilih pemula sebesar $33.6 \%$ pada penyelenggaraan peilihan kepala daerah Kabupaten Ngada tahun 2015

2. Variabel Orientasi calon (X2) berpengaruh signifikan dengan variabel perilaku memilih pemula (Y), sebesar $27.7 \%$ dengan nilai koefisien jalur yang ditemukan sebesar 0,349 dan thitung sebesar 3.084. Orientasi calon sangat mempengaruhi perilaku memilih pemula seebsar $27.7 \%$ pada penyelenggaraan pemilihan kepala daerah Kabupaten Ngada tahun 2015

3. Variabel Orientasi Isu (X3) berpengarh signifikan dengan variabel perilaku memilih pemula (Y), seebsar $18.2 \%$ dengan 
nilai koefisien jalur yang ditemukan sebesar 0,259 dan thitung sebesar 2.816. Orientasi isu sangat mempengaruhi perilaku memilih pemula sebesar $18.2 \%$ pada penyelenggaraan pemilihan kepala daerah Kabupaten Ngada tahun 2015.

Dengan demikian dari hasil uji statistik yang dilakukan perilaku memilih pemula(Y) Kabupaten Ngada sangat dipengaruhi oleh variabel Identifikasi Partai (X1), Orientasi Calon (X2) dan Orientasi Isu (X3).

\section{Daftar Pustaka}

Agustino, L \& Muhamad Agus Yusoff (2009). Kajian Politik dan Masalah Pembangunan. Politik Volume V No 1, 422.

Gafar, A. (1992). Javanese Voters. Yogyakarta: Gajah Mada University Press.

Hendryadi \& Suryani. (2014). Structural Equation Modeling Dengan Lisrel 8.80 (Pedoman Untuk Pemmula). Yogyakarta: Kaukaba Dipantara(Anggota IKAPI).

Mayo, H. B. (1960). An Introduction to Democractic Theory. New York: Oxford University Press.

Mujani, K. A. (1992). Kuasa Rakyat(Analisis tentang Perilaku Memilih dalam Pemilihan Legislatif dan Presiden Indonesia Pasca-Orde baru). Jakarta Selatan: Mizan Pblika.

Nursal, A. (2004). Political Marketing(Strategi Memenangkan Pemilu sebuah pendekatan Baru Kampanye Pemilihan DPRD, DPD, Presiden). Jakarta: PT. Gramedia Pustaka Umum.

Roth, D. (2008). Studi Pemilu Empiris (Sumber, Teori-Teori, Istrumen dan Metode). Jakarta: Für Die Freiheit.

Rudini. (1994). Atas Nama Demokrasi. Jakarta: Biografi Publising.

Sarjono Haryadi \& Winda Julianita (2013). Spss vs Lisrel Sebuah Pengantar Aplikasi Untuk Riset ,Jakarta: Salemba Empat.

Jurnal TAPIs Vol. 14 No.02 Juli-Desember 2018 
Yohana Apaut, dkk: FAKTOR-FAKTOR YANG .......

Setiajid. (2011). Orientasi Politik Yang Mempengaruhi Pemilih pemula Dalam Menggunakan Hak Pilihnya pada pemilihan Walikota semarang Tahun 2010. Jurnal Ingralistik No 1 Th XXII, 20.

Surbakti, R. (1992). Memahami Ilmu Politik. Jakarta: PT. Gramedia Widiasarana Indonesia. 